\title{
Characteristics of the Home Environment Elementary School Students in the Filariasis Endemic Area, Pekalongan City
}

\author{
Sofwan Indarjo ${ }^{1}$, Agus Suwandono ${ }^{2}$, Sulistiyani ${ }^{3}$, Zahroh Shaluhiyah $^{4}$ \\ \{sofwanindarjo@mail.unnes.ac.id ${ }^{1}$, suwandono49@gmail.com ${ }^{2}$, sulistiyani@live.undip.ac.id ${ }^{3}$ \} \\ Universitas Negeri Semarang, Semarang, Central Java, Indonesia ${ }^{1}$ \\ Universitas Diponegoro, Semarang, Central Java, Indonesia ${ }^{2,3}$
}

\begin{abstract}
This research is to see the existence of vector stockpile of vector filariasis. Analytical descriptive research, using a total population of 244 grade 5 elementary school students. The stages of this research used in-depth interviews and direct observation at the students homes in 7 filariasis endemic sub-districts in Pekalongan City. The results of the research on the presence of the drum $24.59 \%$, the existence of the breeding place in the house $53.89 \%$, the existence of the breeding place outside the house within a radius of $100 \mathrm{~m} 29.46 \%$, in the form of the existence of a resting place inside the house $43.30 \%$, the existence of a rest area outside the house within a radius of $100 \mathrm{~m} 24.31 \%$, the presence of wire nets $59.84 \%$. The mosquitoes that cause filariasis can be controlled by maintaining cleanliness around the house by improving the care of all family members.
\end{abstract}

Keywords: Filariasis, student, environment, breeding place, reesting place.

\section{Introduction}

Lymphatic filariasis is a contagious disease caused by filarial worms which is transmitted by various types of mosquitoes including Anopheles, Culex, Mansonia, and Aedes. There are three species of worms that cause filariasis, namely Wuchereria bancrofti, Brugia malayi, Brugia timori [1]. More than 1.4 billion people in the world live in areas at risk of being infected with filariasis, which are spread across 73 countries including Indonesia [2].

Filarisis spread throughout Indonesia. Based on the data, there were 14,932 cases of chronic filariasis from 2002 to 2014, in 2015 there were 13,032 cases of filariasis [2] in 2016 as many as 13,009 and in 2017 as many as 12,677 cases. Of the 514 districts / cities in Indonesia, there are 236 endemic filariasis districts / cities. Of the 236 districts / cities that are endemic for filariasis, 55 districts / cities have administered the mass prevention drug (POMP) for filariasis for 5 consecutive years (5 rounds) [3]. The remaining 181 districts / cities will implement POMP until the year 2020, with a population of 76 million people at risk of being infected with lymphatic filariasis [4][5].

Central Java Province in 2018 cumulatively as many as 397 cases spread in 34 districts / cities [6]. The city of Pekalongan from 2004 to 2017 the number of clinical or positive cases containing microfilaria was 417 people, while those who were chronic (there was swelling of the body or There are 40 people with disabilities [7]. Bondan research in 2014 in Pabean Village, out of 519 blood samples examined, 7 slides were positive for microfilaria (Mf rate $1.3 \%$ ) at the age of 10-19 years, patients with microfilaremia were more found, namely 3 
cases or $2.8 \%$ [8]. In 2018 it was found that 6 people were infected with microfilaria at the age of less than 12 years of SDJ results with a sample of 306 in Kertoharjo district. The prevalence rate of microfilaria in children aged $\leq 10$ years and $>15$ years is proven to be $20 \%$ [9]. Based on data from the Pekalongan City Health Office, adherence to taking filariasis prevention drugs from year to year tends to decline, namely $63.01 \%$ in $2011,60.89 \%$ in 2012 , and $55.86 \%$ in 2013 [10][11].

Nurjazuli's research in Pekalongan City in 2012 on filariasis prevention behavior by using a mosquito net while sleeping, the presence of house ventilation with mosquito netting, using mosquito repellent, not hanging clothes, and environmental management [12][13]. Risk factors for vector presence in the house, environmental improvement, the existence of ditches, ditches, puddles, predators, livestock, bushes, water plants, rice fields and swamps [14][15].

The age of school children is also the object of the prevention of filariasis / POMP which is carried out jointly by the Pekalongan City Health Office [15]. Implementation of the preTransmission Assessment Survey (TAS) and TAS-1 was carried out by the City of Pekalongan to complete the POMP during 5 rounds ( 5 times over a period of 5 years) in 2015; or declared not passing TAS-1, the POMP is re-carried out for 2 rounds (2 times within 2 years) which was carried out the last in 2018 [16].

Filariasis cases in children are known because of the low antifilaria antibody in the category of children and in general, filariasis infection in the pediatric population is rarely given attention / neglected. The risk factors for filariasis in children in Pekalongan City need further research, especially regarding the home environment around children in children. This study looked at the condition of the house, livestock drums, open space or the environment where the vector rest / reproduction was.

\section{Method}

This research is an analytic observational study with a descriptive analytic design using a survey method in the homes of elementary school students in grade 5. An indicator of the endemic environment for filariasis caused by 3 species of filarial worms and transmitted by the Culex quinquefasciatus mosquito. Pekalongan City is a filariasis endemic area with an Mf rate $>1 \%$. The prevalence of filariasis incidence in elementary school age children is $1.98 \%$ in Kota Pekalongan, environmental risk factors for the incidence of filariasis such as house conditions, cattle sheds, open spaces or resting / reproduction environments around the student's house [17].

This research is a descriptive analytic study, to prove the open space or environment where the rest / reproduction of vectors around the student's house is a risk factor for the incidence of filariasis, using a purposive sample of 244 samples of grade 5 elementary school age children. direct observation at the homes of students in 7 sub-district endemic filariasis in Pekalongan City. Kuripan Lor, Kertoharjo, Kuripan Yosorejo, Jenggot, Banyu urip, Pabean, Bandengan and Baros sub-districts [18].

The research location is in 7 villages in three sub-districts in Pekalongan City, namely Kuripan Lor, Kertoharjo, Kuripan Yosorejo, Jenggot, Banyu urip, Pabean, Bandengan and Baros villages. The sample size was determined by using the total sampling technique in the population. The total population of 244 was taken with all respondents in the cluster as many as 244 students. 


\section{Result and Discussion}

The results of research regarding the characteristics of the home environment in grade 5 elementary school students in filariasis endemic areas can be seen in the following table:

Table 1. Characteristics of the primary school student home environment in filariasis endemic areas

\begin{tabular}{|c|c|c|c|}
\hline Characteristic of the home enviroment & $\mathbf{n}$ & $\%$ & Mean \\
\hline $\begin{array}{l}\text { The existence of a livestock pen is attached to a residential } \\
\text { building }\end{array}$ & 60 & 24.59 & 24.59 \\
\hline $\begin{array}{l}\text { The existence of a breeding place in the house, in the form } \\
\text { of: } \\
\text { The bathtub is drained less than } 1 \text { time a week } \\
\text { Water reservoirs that are open / not tightly closed } \\
\text { Vase water is changed less than once a week } \\
\text { Water in the bird's drinking area is changed less than once a } \\
\text { week }\end{array}$ & $\begin{array}{l}172 \\
111 \\
129 \\
144\end{array}$ & $\begin{array}{l}70.49 \\
45.49 \\
52.87 \\
46.72\end{array}$ & 53.89 \\
\hline $\begin{array}{l}\text { The existence of a breeding place outside the house within a } \\
\text { radius of } 100 \mathrm{~m} \text {, in the form of: } \\
\text { Swamps }\end{array}$ & 70 & 28.69 & \\
\hline The sewerage is open and stagnant & 112 & 45.90 & \\
\hline $\begin{array}{l}\text { Stagnant wastewater because it does not have a sewerage } \\
\text { (gutter) }\end{array}$ & 90 & 36.89 & \\
\hline Stagnant water rob & 63 & 25.82 & 29.46 \\
\hline Other dirty puddles: sewers, batik washing water reservoirs & 56 & 22.95 & \\
\hline A deliberate pool of clean water in the form of a fish-free pond & 69 & 28.28 & \\
\hline $\begin{array}{l}\text { Deliberate puddle of clean water in the form of water reservoirs } \\
\text { in water plant pots }\end{array}$ & 47 & 19.26 & \\
\hline $\begin{array}{l}\text { Another deliberate puddle of clean water: water supply for } \\
\text { washing batik }\end{array}$ & 84 & 34.43 & \\
\hline $\begin{array}{l}\text { Unintentional puddle of clean water in the form of clean water / } \\
\text { rain that stagnates on used goods / trash / bamboo fences }\end{array}$ & 56 & 22.95 & \\
\hline \multicolumn{4}{|l|}{ The existence of a resting place in the house } \\
\hline Used clothes hanging & 127 & 52.05 & 43.30 \\
\hline Lush ornamental plants in the house & 68 & 27.87 & \\
\hline Gordin that is rarely washed and opened and closed & 122 & 50 & \\
\hline \multicolumn{4}{|l|}{$\begin{array}{l}\text { The existence of a resting place outside the house within a } \\
\text { radius of } 100 \mathrm{~m}\end{array}$} \\
\hline Lush ornamental plant & 63 & 25.82 & 24.31 \\
\hline Heap of straw & 40 & 16.39 & \\
\hline $\begin{array}{l}\text { Presence of wire gauze throughout the ventilation and in GOOD } \\
\text { condition }\end{array}$ & 146 & 59.84 & 59.84 \\
\hline
\end{tabular}


The existence of breeding places outside the house as much as $29.46 \%$ has an environment that tends to be a breeding place for mosquitoes. Theoretically, environmental management has a relationship with the incidence of filariasis because it is related to efforts to eliminate mosquito breeding and resting places. Management efforts that can be carried out are engineering controls, which are essentially aimed at reducing insect nests (breeding places). Control is carried out by managing the environment (environmental management), namely modifying or manipulating the environment, so that an unsuitable (unfavorable) environment is formed which can prevent or limit vector development. Environmental modification is the safest way for the environment, which does not destroy the balance of nature and does not pollute the environment, but must be done continuously [19]. Control with environmental manipulation, which is related to cleaning or maintaining existing physical facilities so that breeding places or insect rest areas do not form, for example removing or uprooting water plants that grow in ponds or swamps that can suppress the population. Mansonia spp and Culex [20]. According to Umar Fahmi Achmadi, the presence of water habitats is an important factor in the survival of adult mosquitoes to become denser. Mosquitoes lay and hatch their eggs in stagnant or semi-stagnant water, but some use temporary ponds or container habitats such as old tires. The Culex mosquito lays its eggs on a free surface of water, while the female Mansonia mosquito attaches its egg mass to the underside of floating aquatic plants or in water, or at the bottom of water. Stagnant water becomes a breeding ground for mosquitoes [21].

Based on the results of research in the environmental health journal concerning the Relationship of Home Environmental Conditions, Socio-Economic, and Community Behavior with Filariasis Incidence in Pekalongan Selatan District, Pekalongan City, it is stated that standing water around the house will become breeding places for $\mathrm{Cx}$ mosquitoes. Quinquefasciatus, in its life cycle, mosquitoes need very little water $(50 \mathrm{cc})$, mosquitoes can use it as habitat. The mosquito flight distance in general is $1-2 \mathrm{~km}$. So the presence of standing water at this distance will bring humans closer to the filariasis vector mosquito so that the risk of getting filariasis in people who live near standing water is higher than people who live far from standing water. Stagnant water affects the habitat distribution of the filariasis vector and its chain of transmission because it affects and supports the density of the Culex quinquefasciatus mosquito.

The existence of a resting place in the house is based on the results of research that clothes hanging in the house are mosquito resting places after sucking blood so that humans get closer to the filariasis vector mosquito so that the chance of contact with humans is even greater. Based on the results of statistical analysis carried out in this study, there was no significant relationship between the habit of hanging clothes and the incidence of filariasis). The habit of hanging clothes with the incidence of filariasis in this study is caused by temperature and lighting factors in the house that do not support mosquitoes to be used as resting places [22]. The incidence of filariasis is because the respondent has the same habit, namely hanging clothes that are already worn in the house, this is because the clothes still want to be used by the respondent and the respondent's lack of knowledge about the habit of hanging clothes in the house is a place to rest for the mosquito carrying the vector of filariasis because mosquitoes like the place - a place that is protected from sunlight and light.

The existence of resting places outside the house, such as the presence of gauze on the ventilation, as much as $59.84 \%$ of the students' homes use wire netting in good condition. In the transmission of a disease, things that cannot be ignored are the interactions between humans and their behavior and environmental components around humans that have the potential to cause disease. Gauze wire installed on all house vents can serve as a screening to 
prevent mosquitoes from entering the house. So that the effort to install gauze can reduce contact between mosquitoes and residents in the house (Adrias et al, 2012). In the research location, it is known that there are still very few respondents who use gauze in the ventilation of all parts of the house in good condition. This may be because respondents who have used mosquito coils, sprays or spreads, and respondents who have used mosquito nets no longer need to use gauze for the ventilation in every room of their house.

\section{Conclusion}

The conclusion of this research is the existence of breeding places outside and inside the house, the existence of reesting places inside and outside the house and having gauze and education for students because students as agents of change can give changes to the family at home.

\section{Acknowledgments}

Thank you to elementary school students and parents as well as the community in Pekalongan District for being the object of research and contributing to data collection.

\section{References}

[1] World Health Organization. Lymphatic Filariasis [Internet]. Geneva; 2013. 1-107 p. Available from: www.who.int/about/licensing

[2] Balitbangkes. penelitian multicenter filariasis. 1st ed. Jakarta: balitbangkes; 2018. 1-162 p.

[3] Santoso. Filariasis di Indonesia. 1st ed. Badan Penelitian dan Pengembangan Kementerian Kesehatan RI; 2016. 1-191 p.

[4] Kemenkes. Kepmenkes Nomor 1529/Menkes/SK/X/2010 Tentang Pedoman Umum Pengembangan Desa dan Kelurahan Siaga Aktif. 2010. 351.077.Ind p.

[5] Tan M, Kusriastuti R, Savioli L, Hotez PJ. Indonesia: An Emerging Market Economy Beset by Neglected Tropical Diseases (NTDs). PLoS Negl Trop Dis. 2014;8(2):6-10.

[6] Dinas Kesehatan Provinsi Jawa Tengah. Profil Kesehatan Provinsi Jawa Tengah Tahun 2018. Dinkes Prov Jateng. Semarang, Jawa Tengah; 2018. 1-219 p.

[7] Pekalongan dinas kesehatan K. profil kesehatan kota pekalongan. 2016. 1-227 p.

[8] Wahyudi BF, Pramestuti N. Kondisi Filariasis Pasca Pengobatan Massal di Kelurahan Pabean Kecamatan Pekalongan Utara Kota Pekalongan Filariasis Condition After Mass Drug Administration in Pabean Village Pekalongan Utara Subdistrict Pekalongan City. 2016;55-60.

[9] Monica Puspa Sari. Filariasis Limfatik pada Anak-anak. 2014;20(54):34-9.

[10] Chu BK, Deming M, Biritwum NK, Bougma WR, Dorkenoo AM, El-Setouhy M, et al. Transmission Assessment Surveys (TAS) to Define Endpoints for Lymphatic Filariasis Mass Drug Administration: A Multicenter Evaluation. PLoS Negl Trop Dis. 2013;7(12).

[11] Simonsen PE, Mwakitalu ME. Urban lymphatic filariasis. Parasitol Res. 2013;112(1):35-44.

[12] Lismayanti L, Ibrahim K, Meilianingsih L. Pengalaman Hidup Orang Terinfeksi Filariasis. J Keperawatan Padjadjaran. 2013;v1(n1):18-29.

[13] Sunaryo, Rahmadani T. Distribusi Filariasis Limfatik. Balaba. 2008;007(02):2-6.

[14] Syuhada Y, W NE. Studi Kondisi Lingkungan Rumah dan Perilaku Masyarakat Sebagai Faktor Risiko Kejadian Filariasis di Kecamatan Buaran dan Tirto Kabupaten Pekalongan ( Study Of Environmental And Behavioral As Risk Factor Of Filariasis In District Of Buaran And Tirto Pekalo. 2012;11(1):95-101.

[15] Siwiendrayanti A, Pawenang ET, Indarjo S, Hikmah IH. Filariasis Vulnerability Zonation Based on 
Environmental and Behavioural Aspects in Pekalongan City, Indonesia. IOP Conf Ser Earth Environ Sci. 2020;448(1).

[16] Kementerian Kesehatan RI. Petunjuk Teknis. Jakarta: kemenkes; 2017. 1-56 p.

[17] Ike Ani Windiastuti, Suhartono NA. Hubungan Kondisi Lingkungan Rumah, Sosial Ekonomi , dan Perilaku Masyarakat dengan Kejadian Filariasis di Kecamatan Pekalongan Selatan Kota Pekalongan The Association between Environmental House Condistion , Socio-economic, and Behaviour Factors with fi. J Kesehat Lingkung Indones. 2013;12(1):51-7.

[18] Irvine MA, Reimer LJ, Njenga SM, Gunawardena S, Kelly-Hope L, Bockarie M, et al. Modelling strategies to break transmission of lymphatic filariasis - aggregation, adherence and vector competence greatly alter elimination Quantitative analysis of strategies to achieve the 2020 goals for neglected tropical diseases: where are we now? Parasites and Vectors [Internet]. 2015;8(1):119. Available from: http://dx.doi.org/10.1186/s13071-015-1152-3

[19] Ramadhani T. Filariasis Limfatik di Kelurahan Pabean Kota Pekalongan. Kesmas Natl Public Heal J. 2008;3(2):51.

[20] Chandra B. Filariasis Disease. J Kesehat Masy. 2012;7(1):32-8.

[21] Bose K. Control of lymphatic Filariasis through patient empowerment. Wounds International. 2011;

[22] Sipayung M, Wahjuni CU, Devy SR. Pengaruh Lingkungan Biologi dan Upaya Pelayanan Kesehatan terhadap Kejadian Filariasis Limfatik di Kabupaten Sarmi. J Berk Epidemiol [Internet]. 2014;2(2):263-73. Available from: https://media.neliti.com/media/publications/76304-ID-none.pdf 